\title{
PEMBIASAAN MASYARKAT DESA MENGGUNAKAN PERPUSTAKAAN DI DESA KEPUNTEN KECAMATAN TULANGAN SIDOARJO-JAWA TIMUR
}

\author{
Siyaswati ${ }^{1)}$, Wahyu Bandjarjani ${ }^{2)}$, Rikat Eka Prastyawan ${ }^{3)}$, Lambang Erwanto ${ }^{4)}$ \\ 1,2,3,4 FKIP Universitas PGRI Adi Buana Surabaya \\ Email: siyaswati@unipasby.ac
}

\begin{abstract}
Abstrak
Hampir keseluruhan, negara yang maju dan ingin maju, kegiatan membaca merupakan suatu kebutuhan, sama halnya seperti kebutuhan sandang, pangan, dan papan. Membaca adalah satu aktivitas penting bagi terciptanya generasi - generasi yang memiliki wawasan luas dalam segala hal dan sudah barang tentu peka terhadap kondisi lingkungan sekitarnya. Salah satu cara untuk menumbuhkan dan meningkatkan minat baca bagi masyarakat desa sehingga menjadi sebuah budaya, adalah dengan didirikannya perpustakaan, lebih tepatnya Perpustakaan Desa. Dalam PPM ini, tim prodi merumuskan permasalahan bagaimana sudut pandang masyarakat Desa Kepunten terhadap pembiasaan membaca di Perpustakaan Desa terutama tentang pengadaan jumlah dan koleksi buku, minat baca, ketertarikan masyarakat, pengenalan, dan pemanfaatan serta aplikasi literasi Bahasa Inggris. Metode yang dipakai dalam melihat hasil PPM Prodi Pendidikan Bahasa Inggris dideskripsikan secara kuantitatif. Hasil menunjukkan bahwa Pembiasaan Membaca sejak dini yang didukung dengan beraneka ragam bacaan baik dalam Bahasa Indonesia ataupun Bahasa Inggris dapat mendorong masyarakat setempat untuk dapat mengembangkan diri melalui perpustakaan desa yang didukung oleh pemerintah setempat, Program Pengabdian serta Fasilitas yang mendukung agar pengelolaan dan pengembangan Perpustakaan Desa semakin lebih baik.
\end{abstract}

Kata kunci: pengabdian, masyarakat, membaca, perpustakaan.

\begin{abstract}
Almost all developed and progressed countries, reading activities are a necessity, as well as clothing, food and shelter needs. Reading is an important activity for having good generations that have a broad insight in everything and certainly are sensitive to the conditions of the surrounding environment. One way to grow and increase the reading interest for rural communities so that it becomes a culture is to establish a library, more precisely the Village Library. In this activity, the team of English Department formulated the problem of how the perspectives of the Kepunten Village community on reading habits in the Village Library were mainly about the procurement of the number and collection of books, reading interest, community interest, introduction, utilization and application of English literacy. The method used in seeing the results of the Devotion Program to Society (PPM) of English Language Education Program was described quantitatively. The results showed that reading habits from an early age supported by a variety of reading materials in Indonesia or English Language can encourage local people to develop themselves through village libraries supported by the local government, Devotion Programs to Society and Facilities that support the management and development of Village Libraries to better and better.
\end{abstract}

Keywords: devotion, society, reading, library 


\section{PENDAHULUAN}

Ada pepatah yang mengatakan, dengan membaca kita bisa membedah isi dunia. Sebenarnya, dengan membaca seseorang telah melibatkan banyak aspek : meliputi berpikir (to think), merasakan (to feel), dan bertindak melaksanakan hal-hal yang baik dan bermanfaat sebagaimana yang dianjurkan oleh bahan bacaan. Akan tetapi di Negera Indonesia ini, budaya membaca belum sepenuhnya menjadi keseharian, mengingat di satu sisi pendidikan kita belum mampu meletakkkan pondasi dasar bahwa membaca adalah kebutuhan paling vital sebelum jauh menginjak tingkat pendidikan ke arah yang lebih tinggi. Disisi lain, saat ini terjadi dinamika perubahan lingkungan sosial, budaya, dan ekonomi yang sangat cepat. Terbangunnya sebuah peradaban maju tidak terlepas dari pengaruh sumber daya manusia, lingkungan, budaya dan ekonomi.

Dengan sumber daya manusia, maka sebuah kemajuan akan dapat tercapai baik itu kemajuan individu, lingkungan sosial, budaya dan ekonomi. Desa, adalah salah satu parameter dimana sebuah bangsa dapat disebut mempunyai peradaban maju. Karena tidak dipungkiri, sebuah budaya, peradaban sosial dan ekonomi dimulai dari sebuah kelompok kecil dari suatu bangsa, yaitu Desa. Untuk menjadi sebuah desa yang siap menerima perubahan dinamika yang ada serta menyikapi perubahan tersebut secara arif dan bijak tanpa meninggalkan kultur budaya yang ada, tentunya sebuah desa harus memiliki sumber daya manusia (SDM) yang siap menerima tantangan dan perubahan dinamika suatu peradaban.

Di lain sisi, pendidikan sampai saat ini pun belum menjamah $100 \%$ sampai ke setiap wilayah pelosok negeri, terutama desa - desa terpencil yang tidak mendapat perhatian lebih, baik dari pemerintah daerah maupun pusat. Salah satu hal yang dapat dilakukan untuk meningkatkan kualitas sumber daya manusia adalah dengan budaya membaca. Terbangunya sebuah peradaban yang maju tidak terlepas dari pengaruh tingginya minat baca. Dengan membaca, akan mendapatkan sebuah informasi ataupun pengetahuan dalam berbagai hal. Masalah gemar membaca sudah menjadi masalah bangsa, karena rendahnya budaya membaca bagi bangsa kita sudah sangat memperihatinkan, belum lagi di era yang serba teknologi ini, budaya membaca semakin mengalami kemunduran dan kemrosotan. Pasalnya, serbuan media elektornik seperti televisi, radio, internet dan lain sebagainya telah membuat aktivitas membaca menjadi pekerjaan yang dikesampingkan. Tidak hanya generasi instan yang bakal lahir, melainkan manusia manusia yang tidak mengawali satu pekerjaan dari nol dan bersungguh - sungguh, sehingga orisinalitas ide serta beragam inovasi dari bermacam kreativitas menjadi hal yang sangat sulit direalisasikan, apalagi dikembangkan. Salah satu cara untuk menumbuhkan dan meningkatkan minat baca bagi masyarakat desa sehingga menjadi sebuah budaya, adalah dengan didirikannya perpustakaan, lebih tepatnya Perpustakaan Desa.

Dengan adanya perpustakaan, diharapkan masyarakat desa akan mendapatkan suatu informasi maupun wawasan dan hal tersebut dapat menjadikan masyarakat lebih produktif, kreatif, berwawasan lebih luas sehingga akan berpengaruh terhadap diri sendiri, masyarakat, lingkungan sosial, budaya dan ekonomi. Perpustakaan desa sangatlah memberikan dampak yang sangat positif terhadap warga yang berada di desa tersebut dan sekitarnya. Masyarakat atau pengunjung bisa mendapatkan berbagai informasi dari buku yang dibacanya, mulai dari informasi keagamaan, pendidikan, pertanian, peternakan, ekonomi, bisnis, teknologi, kesehatan dan sebagainya.

Sebagai nilai tambah, dengan adanya perpustakaan tersebut maka diharapkan akan dapat menumbuhkan, meningkatkan dan menjadikan membaca menjadi sebuah budaya. Fungsi perpustakaan selain dapat meningkatkan minat baca, juga sebagai fungsi edukatif dan informasi. Fungsi edukatif dan informasi, adalah dengan adanya perpustakaan desa dapat meningkatkan kemampuan masyarakat dalam membaca, selain itu perpustakaan desa 
tentunya menyediakan informasi buku-buku yang disesuaikan dengan masyarakatnya misalkan buku tentang pertanian, peternakan, wirausaha, pendidikkan, budaya, sejarah, koran, majalah dll.

Selain fungsi edukatif dan informasi, perpustakaan juga dapat dijadikan sebagai fungsi riset. Adanya informasi tentang sebuah riset berbagai bidang akan dapat mempermudah masyarakat apabila ingin mengaplikasikan riset tersebut, misalnya riset di bidang pertanian, perkebunan maupun peternakan. Kecenderungan masyarakat menganggap bahwa bisa membaca suatu keharusan, namun tidak terlalu menganggap penting kemampuan membaca dijadikan menjadi budaya membaca. Budaya membaca bagi masyarakat desa masih kurang berjalan dengan baik, karena mereka lebih senang menonton televisi. Dengan kemajuan peradaban kita tidak bisa melarang atau bahkan membatasi kebiasaan masyarakat.

Selain Perpustakaan, keberadaan Taman Bacaan Masyarakat atau TBM dan komunitas baca sangat berperan penting dalam mewujudkan masyarakat yang sadar dan peduli terhadap budaya membaca. Misalnya, seorang petani membaca buku tentang pertanian maka petani tersebut mendapatkan ilmu tentang bercocok tanam yang modern, mengerti berbagai hama penyakit tanaman dan sebagainya sehingga ilmu yang didapatkan secara tidak langsung bermanfaat bagi petani tersebut. Selain tantangan diatas, kebanyakan masyarakat pedesaan masih ada yang belum bisa membaca atau buta huruf karena di masa mudanya mereka tidak mengeyam pendidikan secara maksimal dan tidak lulus dari jenjang sekolah dasar.

Untuk mengatasi permasalahan tersebut, pemerintah selalu berupaya memberikan yang terbaik untuk masyarakat diantaranya dengan mencanangkan progam pembelajaran kejar paket A, B dan C. Di era globalisasi dan modernisasi ini ternyata budaya membaca sangatlah berharga. Karena dengan membaca kita menjadi tahu apa yang belum kita ketahui sebelumnya dan wawasan semakin bertambah. Namun demikian, banyaknya kendala untuk mewujudkan pembiasaan masyarakat Desa menggunakan Perpustakaan ataupun Taman Bacaan di suatu desa akan mendapatkan tantangan dari hiburan-hiburan lain yang ada di masyarakat.

Berdasarkan Instruksi Menteri Dalam

Negeri dan Otonomi Daerah Nomor 50 Tahun 2000. Perpustakaan Umum Desa/Kelurahan berfungsi sebagai Perpustakaan Cabang sebagaimana halnya dengan Perpustakaan Umum Kecamatan. Secara umum, perpustakaan mempunyai peranan yang sangat vital bagi peningkatan kualitas sumber daya manusia. Pertama, sebagai jantung pendidikan dan ilmu pengetahuan. Kedua sebagai pusat pengumpulan dan penyimpanan sumber pengetahun dan informasi. Ketiga, sebagai social center, yaitu pusat kegiatan masyarakat setempat.

Berdsarkan hasil pengamatan dilapangan, permasalah yang dihadapi oleh perpustakaan desa adalah (1) Kuantitas dan keberagaman koleksi perpustakaan yang belum memenuhi ketentuan yang harus dimiliki suatu perpustakaan desa, (2) minat baca masyarakat desa yang masih rendah, (3) kurangnya daya tarik masyarakat terhadap perpustakaan, (4) tempat yang kurang nyaman dan menyenangkan. Perpustakaan Desa/Kelurahan diharapkan mempunyai koleksi dasar sekurang-kurangnya 1000 judul (2500 eksemplar).

Adapun komposisi jenis koleksi yang dimiliki Perpustakaan Desa/Kelurahan seyogyanya adalah dengan perbandingan non fiksi $60 \%$ dan fiksi $40 \%$. Dengan prosentase non fiksi lebih besar. Dimaksudkan agar masyarakat pemakai (pedesaan) dapat memperluas pengetahuan umum dan keterampilan yang diperlukan dalam kegiatan sehari-hari. Prosentasi ilmu pengetahuan praktis $60-70 \%$ dari total buku-buku non fiksi. Buku-buku yang dapat menunjang pekerjaan pokok masyarakat setempat harus diupayakan sehingga dengan berpedoman pada buku-buku praktis tersebut pengasilannya dapat bertambah. Sedangkan untuk menggairahkan minat baca masyarakat dan sekaligus sebagai sarana rekreasi. Maka Perpustakaan Desa/Kelurahaan diharapkan 
dilengkapi dengan koleksi buku fiksi (buku cerita) yang seyogyanya dapat membuka wawasan dan memperhalus budi pekerti seperti;buku cerita, buku ilmu pengetahuan popular, buku-buku sejarah, kisah-kisah nabi dan lain-lain.

Dalam pengadaan koleksi harus memperhatikan kebutuhan masyarakat pemaki jasa perpustakaan serta tujuan dan misi yang diemban perpustakaan. Perpustakaan Desa/Kelurahan melayani segala lapisan dan golongan masyarakat yang beraneka ragam. Oleh karena itu pengadaan koleksi harus memperhatikan keanekaragaman tersebut (politik, sosial, budaya, dan keamanan setempat). Disamping permasalahn mengenai kurangnya koleksi perpustakaan, permasalahn mengenai minat baca masyarkat yang masih rendah juga ikut berpengaruh. Hal ini salah semuanya disebabkan oleh kurangnya daya tarik masyarakat terhadap perpustakaan sehingga kurangnya minat baca itu akan muncul dan merebak menjangkiti masyarakat. Untuk mengatasi masalah tersebut, alternative solusinya yaitu dengan model perpustakaan yang lain dari biasanya yaitu perpustakaan alam yang unik sebagai daya tarik kecintaan masyarkaat terhadap perpustakaan.

Untuk mengatasi permasalah mengenai kurang minatnya masyatrakat terhadap perpustakaan, tempat yang nyaman, suasan yang menyenankan bagi pengunjung, bahkan untuk selanjutnya, suasana yang menyenangkan ini dapat menarik minat orang-orang yang ada awalnya enggan datang ke perpustakaan menjadi suka datang ke perpustakaan. Jadi, sebagi langkah awal, perpustakaan harus mampu memberikan daya tarik bagi pengunjung terlebih dahulu, serta perpustakaan desa harus dapat memiliki peran untuk meningkatkan tingkat literasi masyarakat setempat. Permasalahan yang dihadapi oleh perpustakaan desa ini juga dihadapi oelh perpustakaan desa Kepunten, Kecamatan Tulangan, Kabupaten Sidoarjo, Provinsi Jawa Timur.

Kecamatan Tulangan merupakan salah satu kecamatan dari 18 kecamatan yang ada di Kabupaten Sidoarjo, dengan luas rata-rata tiap kecamatan itu yakni 34,61 km2. Menurut hasil Sensus Penduduk tahun 2010, jumlah penduduknya adalah 58.358 jiwa dengan komposisi laki-laki 29.183 dan perempuan 29.175. Jika dilihat dari aspek ekonomi, banyak yang menggantukan kehidupan pada sector Swasta. Sedangkan untuk peringkat kedua dimiliki oleh kelompok pedagang. Peringkat ketiga sector pekerjaan yang banyak dimiliki oleh kelompok masyarakat Tulangan adalah dalam sector jasa.

Dari aspek keagamaan, penduduk kecamatan ini paling banyak menganut agama Islam (63.537) jiwa). Kedua adalah agama Kristen (223 jiwa). Ketiga adalah agama Katolik (77 jiwa). Keempat adalah agama Hindu (18 jiwa) dan kelima adalah agama Budha (7 jiwa). Berdasarkan tingkat pendidikan, masyarakat yang berdomisili di Kecamatan ini setidanya memiliki enam jenis pendidikan yakni, masyarakat dengan jenjang pendidikan TK, masyarakat dengan jenjang pendidikan SD, SLTP, SLTA, Diplma, dan Sarjana. Paling banyak masyarakat berpendidikan SLTA, peringkat kedua dimiliki oelh pneduduk yang berpendidikan TK, kemudian SD, SLTP, Sarjana, kemudian Diploma.

Tingkat pendidikan merupakan faktor penting yang dimiliki oleh daerah sehingga dengan penduduk yang memiliki tingkat pendidikan tinggi dimungkinkan memiliki sumber daya manusia (SDM) yang berkualitas. Disisi lain, Adanya tempat pendidikan sebagai fasilitas penunjang untuk kegiatan belajar mengajar penting diperhatikan. Ketersebaran fasilitas pendidikan di tiap-tiap jenjang mengunkinkan masyarakat agar mudah untuk menjangkau, salah satunya adalah melalui pengadaan dan permberdayaan perpustakaan desa. Berdasarkan hasil pengamatan di lapangan yang telah diuraikan diatas permasalahan yang dihadapi oleh perpustakaan desa di Kecamatan Tulangan Kabupaten Sidoarjo adalah sebagai berikut:

1. Kurangnya jumlah dan jenis koleksi perpustakaan

2. Kurangnya minat baca masyarakat desa. 
3. Kurangnya ketertarikan masyarakat desa terhadap perpustakaan desa.

4. Kurang dalam pengenalan Bahasa Inggris di masyarakat.

Berdasarkan permasalah yang dihadapi oleh perpustakaan desa tersebut, maka upaya dan langkah nyata akan dilakukan oleh Program Studi Pendidikan Bahasa Inggris Universitas GRI Adibuana Surabaya sebagai salah satu realisasi program pengabdian kepada masyarakat di tahun 2018 ini adalah "Bagaimana sudut pandang masyarakat Desa Kepunten terhadap pembiasaan membaca di Perpustakaan Desa terutama tentang pengadaan jumlah dan koleksi buku, minat baca, ketertarikan masyarakat, pengenalan, dan pemanfaatan serta aplikasi literasi Bahasa Inggris".

\section{Tujuan Kegiataan}

Pada umumnya kegiatan pengabdian masyarakat ini bertujuan untuk memberdayakan penggunaan perpustakaan desa di desa Kepunten Kecamatan Tulangan, Kabupaten Sidoarjo. Tujuan yang lebih spesifik dari kegiatan ini adalah:

i. Membantu pengadaan jumlah dan jenis koleksi perpustakaan desa terutama Literasi Bahasa Inggris.

ii. Meningkatkan minat baca dan tingkat literacy masyarakat desa

iii. Meningkatkan ketertarikan masyarakat terhadap perpustakaan desa.

iv. Mengenalkan literasi bahasa Inggris masyarakat desa.

v. Memanfaatakan dan

Mengaplikasikan sarana dan fasilitas untuk meningkatkan literasi Bahasa Inggris di masyarakat desa.

\section{Sasaran Program}

Sasaran Program dari Kegiatan Pengabdian Masyaakat (PPM) 2018 Program Studi Pendidikan Bahasa Inggris Fakultas Keguruan dan Ilmu Pendidikan adalah Masyarakat Desa, khususnya Desa Kepunten Kecamatan Tulangan, Kabupaten Sidoarjo.

\section{METODE PELAKSANAAN}

Metode yang digunakan dalam kegiatan ini adalah

1. Model pendampingan masyarakat untuk pemberdayaan perpustakaan desa

Model pendampingan kepada masyarakat bertujuan sebagai upaya mengembangkan pola-pola program edukasi kepada masyarakat untuk meningkatkan sumber daya manusia melalui perpustakaan desa serta peningkatan fasilitas perpustakaan desa.

2. Model perencanaan atau perancangan perpustakaan desa.

Model perencanaan atau perancangan pepustakaan des ini dibuat dalam bentuk gambar sederhana tentang struktur dan fasilitas perpustakaan desa.

3. Model tindak lanjut

Model tindak lanjut ini diguankan karena keberhasilan di dalam program ini. Hal ini tidak akan dicapai hanya dalam waktu singkat sehingga diterapkan tindak lanjut yang berkesinambungan.

Data yang diperoleh berupa wawancara ataupun angket didiskripsikan secara kuantitatif berupa grafik agar mudah untuk dipahami dan dimengerti.

\section{Tempat Dan Waktu Kegiatan}

Pelaksanaan kegiatan pemberdayaan Perpustakaan Desa di Desa Kepunten, Kecamatan Tulangan Sidoarjo, Provinsi Jawa Timu oleh Tin KKN PPM Program Studi Pendidikan Bahasa Inggris dilaksanakan pada tanggal 1 Februari s/d 30 Maret 2018. Waktu pelakasanaan tersebut bersifat fleksibel melihat situasi dan kondisi di lapangan.

\section{HASIL PELAKSANAAN}

Pentingnya Pembiasaan Membaca

Tanggal 12 Februai 2018, Ibu Siyas memberikan penyuluhan kepada masyarakat tentang pentingnya Pembiasaan Membaca di Desa Kepunten, Kecamatan Tulangan Kabupaten Sidoarjo. Dalam kegiatan 
Pengabdian ini, Ibu Siyas menyampaikan beberapa konsep tentang cara-cara agar anak dapat terbiasa dengan membaca. Beberapa yang beliau sampaikan dapat diperinci sebagai berikut; Setelah materi tentang pembiasaan membaca disampaikan ke masyarakat Desa Kepunten Kecamatan Tulangan Kabupaten Sidoarjo, tim Prodi menyebarkan angket untuk mendapatkan pandangan masyarakat tentang Bagaimana sudut pandang masyarakat Desa Kepunten terhadap pembiasaan membaca di Perpustakaan Desa. Dari 23 Angket yang disebarkan dapat diperoleh pendapat masyarakat sebagai berikut;
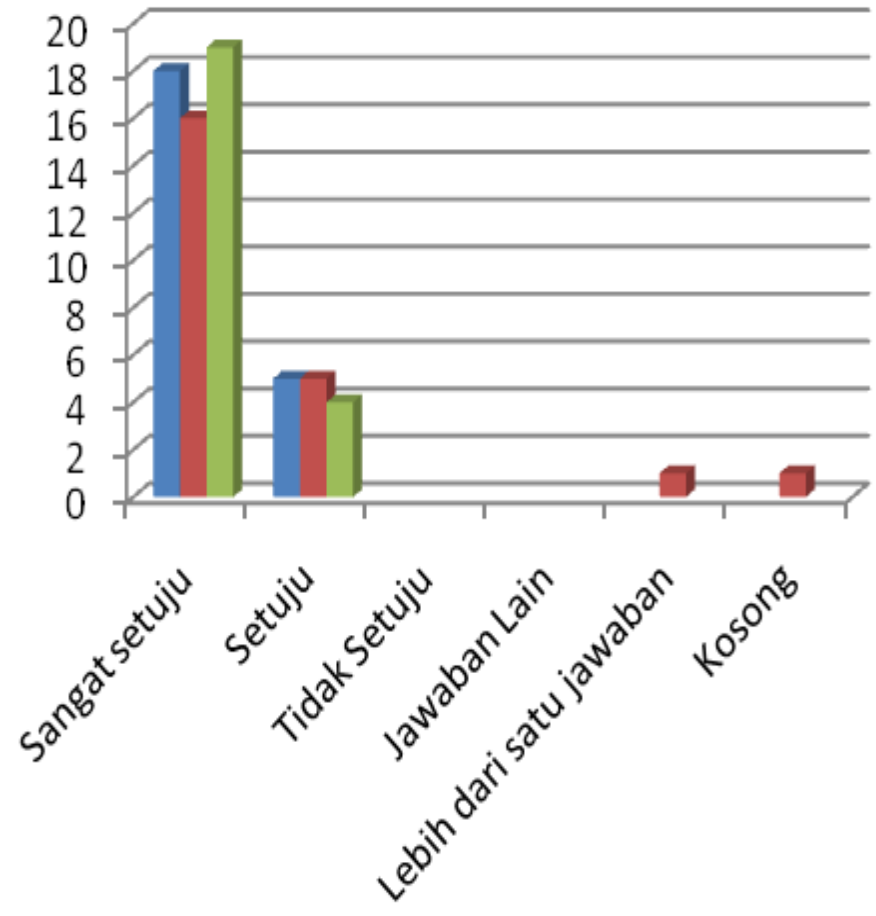

1 Pembiasaan Membaca harus dibiasakan sejak usia dini

\section{Budaya membaca dapat mengarahkan masa depan anak lebih baik}

3 Orang Tua memiliki peran penting untuk membuat anak gemar membaca
Masyarakat Desa Kepunten berpendapat bahwa Orang Tua memiliki peran penting untuk membuat anak gemar membaca. Selain dari faktor orang tua, Pembiasaan membaca juga perlu ditanamkan. Masyarakat percaya bahwa budaya membaca dapat mengarahkan masa depan anak lebih baik. Dalam acara Pengabdian Masyarakat tersebut juga dibuka sesi tanya jawab kepada masyarakat. Ada seseorang yang bertanya apakah hp yang sedang booming di Era saat ini dapat mengurangi budaya membaca. Narasumber kemudian menjawabnya bahwa penggunaan HP terutama smartphone di Era saat ini memiliki segi positif apabila digunakan dengan bijak. Smartphone yang bisa terhubung dengan internet akan dapat membantu anak dalam mencari informasi apapun yang dibutuhkan.

Hal ini tentunya akan lebih bijak apabila diikuti dengan dampingan orang tua. Melihat hasil sudut pandang masyarakat yang diperoleh dari angket, dapat disimpulkan bahwa ada tiga hal yang dapat dikembangkan dan menjadi poin penting terkait dengan pembiasaan membaca yaitu faktor pendampingan orang tua, kesadaran akan pentingnya gemar membaca demi masa depan yang lebih baik, serta pembiasaan untuk gemar membaca sejak usia dini.

\section{Pengembangan Perpustakaan Desa}

Pengembangan perpustakaan desa menjadi topik yang kedua yang disampaikan oleh Ibu Dra. Hj. Wahju Bandjarjani, M.Pd 
pada tanggal 19 Februari 2018. Beliau menyampaikan tentang cara-cara pengembangan Perpustakaan Desa. Untuk menarik minat membaca ataupun pembiasaan gemar membaca sejak usia dini, perlu adanya fasilitas dan minat yang bagus agar dapat mewujudkan tujuan serta adanya dampak dari pembiasaan itu. Hal ini tentu akan terkait dengan pengembangan perpustakaan desa. Ibu Wahju selaku narasumber dalam Program Pengabdian ini memberikan materi tentang cara-cara pengembangan perpustakaan desa dan diakhir dari pemberian materi tersebut, di dapatkan pendapat dari masyarakat desa kepunten terkait dengan pengembangan Perpustakaan Desa yang disajikan dalam grafik agar lebih mudah untuk dipahami.

Dalam pengembangan perpustakaan Desa Ibu Wahju Bandjarjani menyampaikan bahwa pembentukan pengurus Perpustakaan Desa perlu untuk dibentuk terlebih dahulu. Setelah pembentukan pengurus dilakukan, mengklasifikasi kan bahan bacaan sangat penting untuk dilakukan karena akan memudahkan pembaca dalam mencari informasi yang dibutuhkan. Selain mempermudah, hal tersebut dapat juga menarik minat pembaca karena bahan bacaan tertata rapi serta terpilah-pilah sesuai dengan topic bacaan tersebut.

Hal yang perlu dilakukan setelah mengklasifikasi bahan bacaan sesuai dengan topiknya yaitu membuat SOP (Standar Operational Procedure) Tata Cara peminjaman, tata tertib perpustakaan, ataupun yang lainnya agar bisa memberikan kenyamanan bagi pengunjung. Setelah tata tertib dibuat, menyebarluaskan informasi tentang adanya perpustakaan desa menjadi langkah maju untuk pengembangan. Hal ini dilakukan agar perpustakaan desa dapat memiliki arti penting dan membawa manfaat bagi masyarakat. Banyak sedikitnya pengunjung terkadang sangat dipengaruhi oleh informasi yang masyarakat ketahui.

Mereka tidak berkunjung karena memang tidak tahu bahwa di tempat tersebut ada perpustakaan Desa. Salah satu langkah untuk menyebarluaskan ini bisa dilakukan dengan media sosial yang saat ini hampir semua lapisan masyarakat menggunakannya terutama di kalangan generasi muda. Pandangan masyarakat Desa Kepunten terhadap pengelolaan Perpustakaan disajikan sebagai berikut;

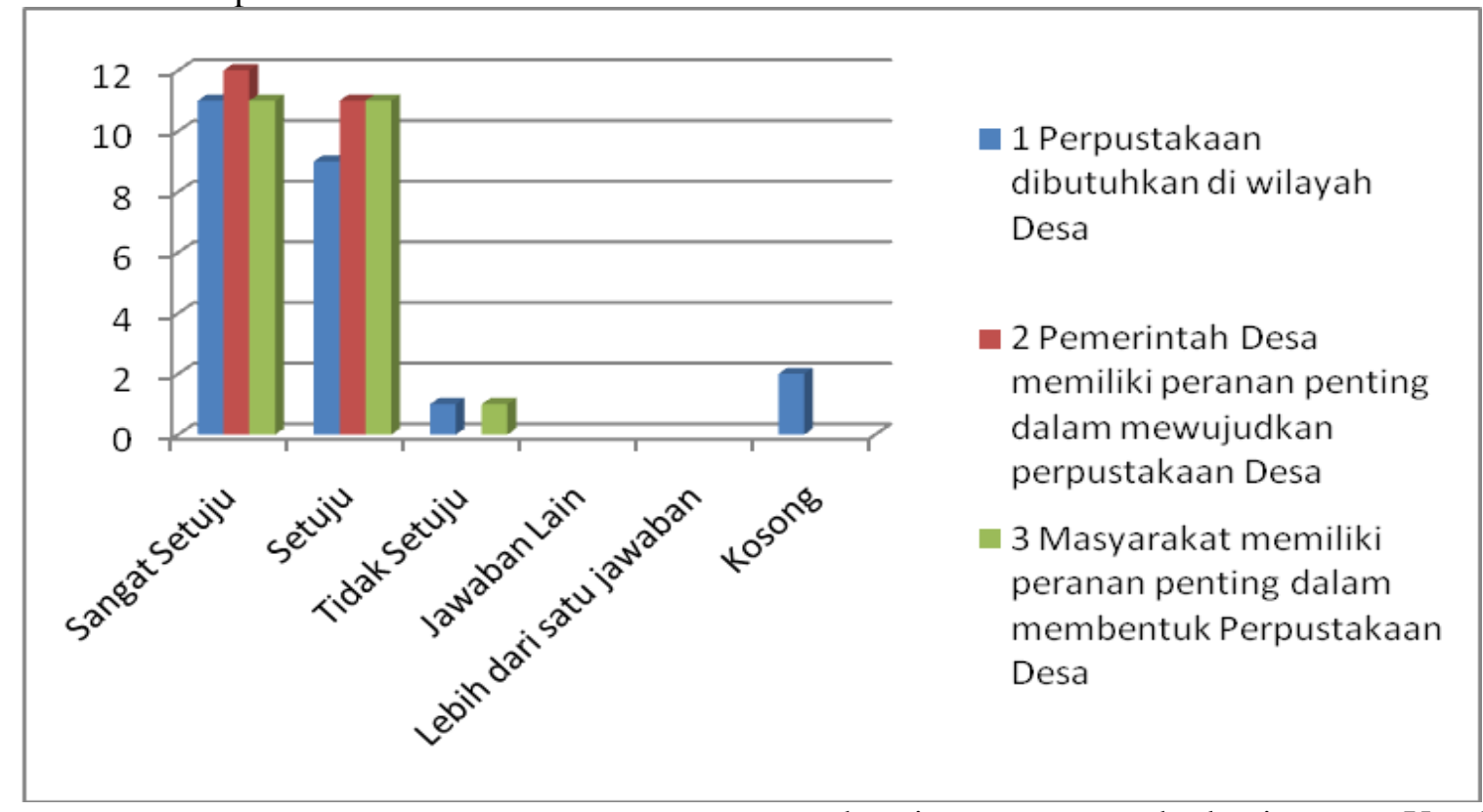

Grafik diatas menunjukkan bahwa masyarakat benar-benar membutuhkan sebua perpustakaan sebagai sumber ilmu yang bisa sebagai tempat berkunjung. Untuk mewujudkan hal tersebut peran pemerintah desa sangat penting dalam mewujudkan perpustakaan desa. Selain pemerintah, peran 
masyarakat juga dibutuhkan dalam pengembangan perpustakaan tersebut misalnya dengan menyebarluaskan informasi melalui media sosial ataupun dari interaksi sosial yang dilakukan. Dari kajian diatas dapat disimpulkan bahwa dalam pengembangan perpustakaan desa, sangat dibutuhkan peran pemerintah serta masyarakat yang saling bersinergi agar keberadaan perpustakaan desa dapat memberikan manfaat yang berarti.

\section{Pengelolaan Perpustakaan Desa}

Topik tentang pengelolaan perpustakaan desa disampaikan oleh Bapak Rikat Eka Prastyawan, M.Pd. tanggal 26 Februari 2018. Dalam bagian ini disampaikan bahwa selain pengembangan, pengelolaan Perpustakaan Desa sangat penting dilakukan agar perpustakaan desa mampu bertahan dalam menjaga minat baca masyarakat dengan cara memberikan pelayanan sebaik mungkin kepada pengunjung perpustakaan. Salah satu cara untuk dapat mempertahankan kebiasaan tersebut dengan menambah referensi bacaan ataupun dengan saling menukar sumber bacaan antar perpustakaan Desa. Hal ini penting dilakukan karena ditinjau dari segi keilmuan tidak akan memberikan kebosanan kepada pengunjung apabila koleksi bacaan di perpustakaan beranekaragam dan dapat silih berganti. Dalam bagian ini dijelaskan pula bahwa pengelolaan perpustakaan yang benar akan dapat dijadikan acuan sebagai bentuk pembelajaran manajemen yang efektif.
Selain koleksi buku yang harus beragam dan silih berganti, fasilitas lainnya yang perlu diberikan dalam era sekarang yaitu adanya komuputer dan internet. Komputer saat ini sudah menjadi keharusan di perpustakaan karena Era digitalisasi ini akan membawa kemudahan bagi pengunjung untuk menemukan sumber bacaan yang diinginkan. Pencarian manual dengan menggunakan buku katalog tetap disediakan dengan menambahkan fasilitas catalog melalui computer dengan menggunakan software gratis yang dapat diunduh melalui internet ataupun application store. Dalam pengelolaan ini dibutuhkan Sumber Daya Manusia yang mendukung untuk dapat memasukkan daftar buku bacaan secara manual untuk dimasukkan dalam list hard disk komputer sehingga kalaupun masih terkendala dengan tidak adanya jaringan internet, tetap dapat dilakukan dan digunakan secara efektif. Hal berikutnya yaitu adanya internet. Internet saat ini mampu memberikan informasi apapun yang pembaca inginkan. Hal ini sebagai daya tarik tersendiri bagi pengunjung untuk dapat merubah paradigma masyarakat tentang kemajuan teknologi yang tidak hanya berdampak negative dengan meninggalkan cara-cara manual, tetapi dapat memberikan pengaruh yang sangat positif apabila digunakan secara bijak. Setelah memberikan materi tentang pengelolaan perpustakaan desa, dari program pengabdian ini didapatkan pula pandangan masyarakat yang dapat dilihat melalui grafik berikut:

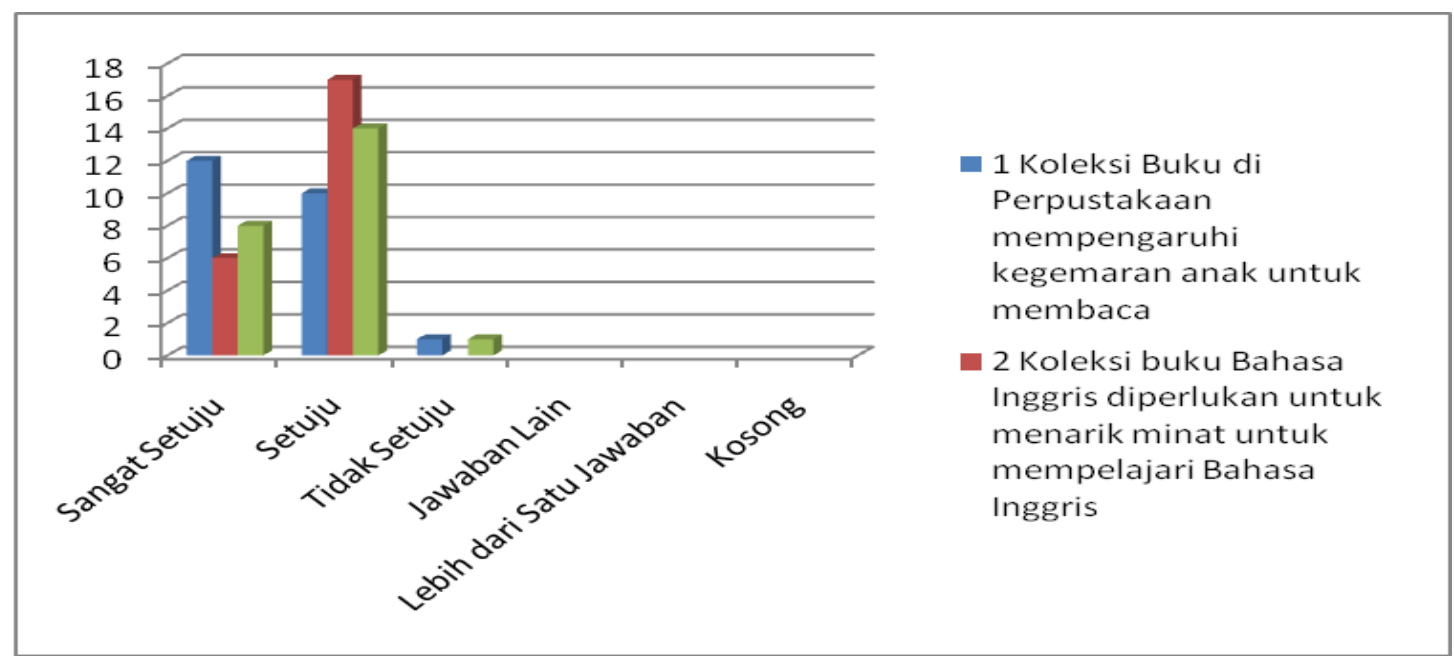


Dari pendapat masyarkat yang dianalisis melalui angket, diperoleh pernyataan bahwa koleksi buku di perpustakaan mempengaruhi kegemaran anak untuk membaca. Selain itu koleksi buku yang berbahasa Inggris juga perlu diberikan untuk memberikan fasilitas lebih dan mengenal bahasa inggris sejak dini agar tidak terkendala dengan kesulitan berbahasa untuk mendapatkan ilmu yang diinginkan.

\section{Peran PPM (Program Pengabdian Masyarakat)}

Tahap ini dilakukan tanggal 2 Maret 2018 yang disampaikan oleh Bapak Lambang Erwanto Suyadjid, S.S., M.Pd. yang terkait dengan peranan Program Pengabdian Masyarakat. Narasumber memberikan penjelasan bahwa Program Pengabdian Masyarakat merupakan salah satu tridarma perguruan tinggi yang harus dilakukan oleh setiap dosen. Selama PPM tim prodi mencoba untuk menggali minat-minat masyarakat ataupun kebutuhan masyarakat yang dibutuhkan agar dapat membantu dalam mengembangkan potensi dari dalam diri masyarakat itu sendiri terutama dalam kajian ilmu bahasa inggris. Selain menyampaikan materi yang terkait dengan Peran PPM Prodi Pendidikan Bahasa Inggris, nara sumber juga melakukan kegiatan promo prodi bahasa Inggris.
Dalam bagian ini narasumber menjelaskan bahwa Prodi Pendidikan Bahasa Inggris sudah mendapatkan akreditasi B dengan memiliki Sumber Daya Manusia yang sesuai dengan bidangnya. Program Studi Pendidikan Bahasa Inggris memiliki 16 Dosen Tetap yang terdiri dari kajian ilmu pendidikan, sastra, ataupun linguistik. Program Pendidikan Bahasa Inggris telah mampu memberikan serta mendidik putra-putri bangsa yang berdaya saing tinggi. Hal ini didukung dengan Dosen-dosen Bahasa Inggris yang tidak hanya memiliki lulusan dalam negeri saja, tetapi juga di dukung oleh lulusan luar negeri serta memberikan kesempatan kepada mahasiswa untuk dapat menimba ilmu di luar negeri tanpa menghambat proses belajar di Program Studi Pendidikan Bahasa Inggris yang telah di atur dalam kurikulum untuk dapat lulus dalam waktu 4 tahun. Terselenggarakannya Seminar Nasional setiap tahun serta telah mampu menyelenggarakan seminar tingkat internasional yang diikuti oleh berbagai Negara. Setelah memberikan materi terkait dengan peran PPM Program Studi Pendidikan Bahasa Inggris, tim Prodi juga menggali pendapat masyarakat Desa Kepunten terkait dengan PPM yang sedang diselenggarakan. Berikut grafik yang dapat disajikan:

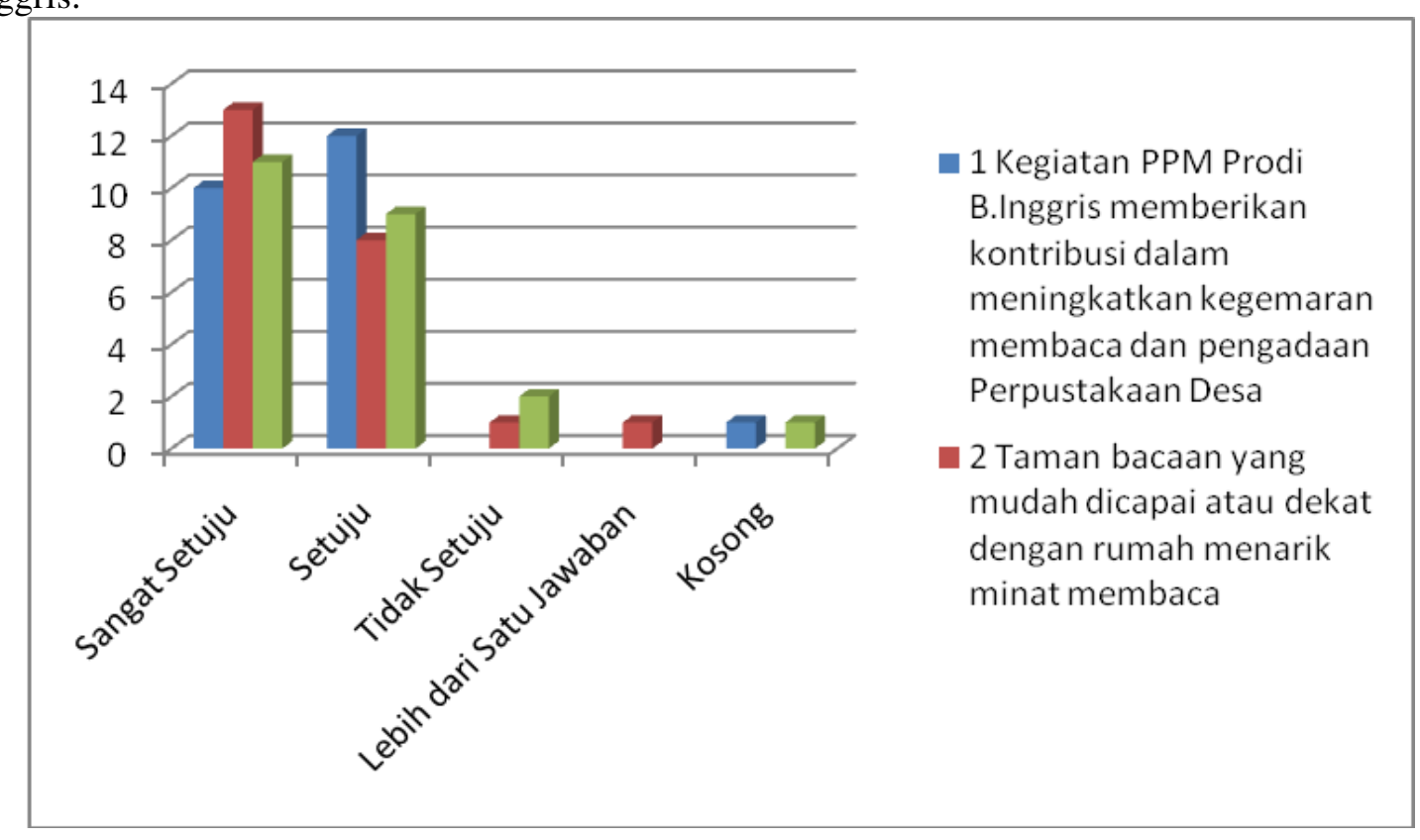


Dari grafik diatas, dapat diketahui bahwa Program PPM mampu memberikan kontribusi dalam meningkatakan kegemaran membaca dan dalam pengadaan Perpustakaan Desa. Selain itu masyarakat juga menginginkan lokasi perpustakaan harus mudah dijangkau oleh masyarakat sehingga bisa efektif dan efisien. Dari pendapat masyarakat diatas dapat disimpulkan bahwa program PPM sangat dibutuhkan masyarakat untuk dapat mengembangkan potensi-potensi yang ada dari dalam diri masyarakat itu sendiri. Salah satunya dengan memberikan suguhan pengetahuan yang mampu untuk mengelola, mengembangkan serta memberdayakan masyarakat melalui Perpustakaan Desa.

\section{Peranan Pustakawan}

Tahap ini dilakukan tanggal 9 Maret 2018 yang dipresentasikan oleh Ibu Titah Kinasih, S.Pd., M.Si. terkait dengan peran pustakawan. Dalam sesi ini, narasumber menjelaskan langkah-langkah apa yang sebaiknya dilakukan oleh pustakawan dalam mengelola perpustakaan. Peran pustakawan, semakin berkembang dari waktu ke waktu.Kini pustakawan tidak hanya melayani sirkulasi buku, tapi dituntut untuk dapatmemberikan informasi secara cepat, tepat, akurat dan efisien dari segi waktu dan biaya.Pustakawan dituntut untuk mengembangkan kompetensi diri, inisiatif, kreatif, dan pelayanan yang baik kepada pengunjung termasuk keramahan yang sangat dibutuhkan. Berikut beberapa saran yang disampaikan oleh narasumber terkait dengan peran pustakawan:

a. Menciptakan lingkungan yang saling mempercayai dan saling menghargai, contoh: Menghargai kelebihan dan kemampuan orang lain. Mengenali kekuatan sendiri dan kekuatan orang lain dengan seimbang. Membantu orang lain untuk mengoptimalkan

b. Memiliki keahlian berkomunikasi yang efektif,

contoh: Mempresentasikan gagasan secara jelas dan antusias. Menulis teks secara jelas dan mudah dimengerti. Menggunakan bahasa yang umum. Meminta umpan balik dalam keahlian berkomunikasi dan menggunakannya untuk perbaikan diri.

c. Bekerja dengan baik dengan sesama anggota tim,

contoh :Mempelajari kebijaksanaan tim dan mencari peluang untuk partisipasi tim: Ambil tanggung jawab dalam tim, baik di dalam maupun di luar perpustakaan. Membimbing anggota tim lainnya. Meminta bimbingan dari anggota tim lain bila diperlukan.

d. Mempunyai sifat pemimpin,

Contoh : Mempelajari dan mengembangkan kualitas seorang pemimpin yang baik dan mengetahui cara untuk melatih kepemimpinan tersebut. Dapat membagi kompetensi kepemimpinan dengan yang lain dan memberikan kesempatan orang lain untuk berkompetensi sebagai pemimpin.

e. Belajar terus menerus dan mempunyai perencanaan karir pribadi,

contoh :Meniti karir dengan belajar secara terus menerus dan mengembangkan pengetahuan. Memiliki tanggung jawab pribadi untuk perencanaan karir jangka panjang dan mencari kesempatan untuk belajar dan memperkaya ilmu.

f. Memahami nilai solidaritas dan jaringan profesional;

contoh :Berkompetensi aktif dalam asosiasi Pustakawan dan asosiasi profesional lainnya. Menggunakan peluang ini untuk berbagi pengetahuan dan keahlian, untuk studi banding dengan penyedia layanan informasi lainnya, membentuk kemitraan dan aliansi.

g. Bersifat fleksibel dan positif menghadapi perubahan terus menerus, contoh :Dapat menerima tanggung jawab yang berbeda dalam waktu 
yang berbeda pula dan merespon kebutuhan akan perubahan. Memelihara sifat positif dan membantu orang lain untuk melakukan hal yang sama. Menolong orang lain untuk mengembangkan gagasan mereka dengan cara menyediakan informasi yang benar.
Selain memberikan materi tersebut, narasumber juga menggali pendapat masyarakat terkait peran pustakawan yang diperoleh dari hasil angket setelah Program Pengabdian Masyarakat dilakukan. Berikut grafik tentang peran pustakawan di Perpustakaan Desa.

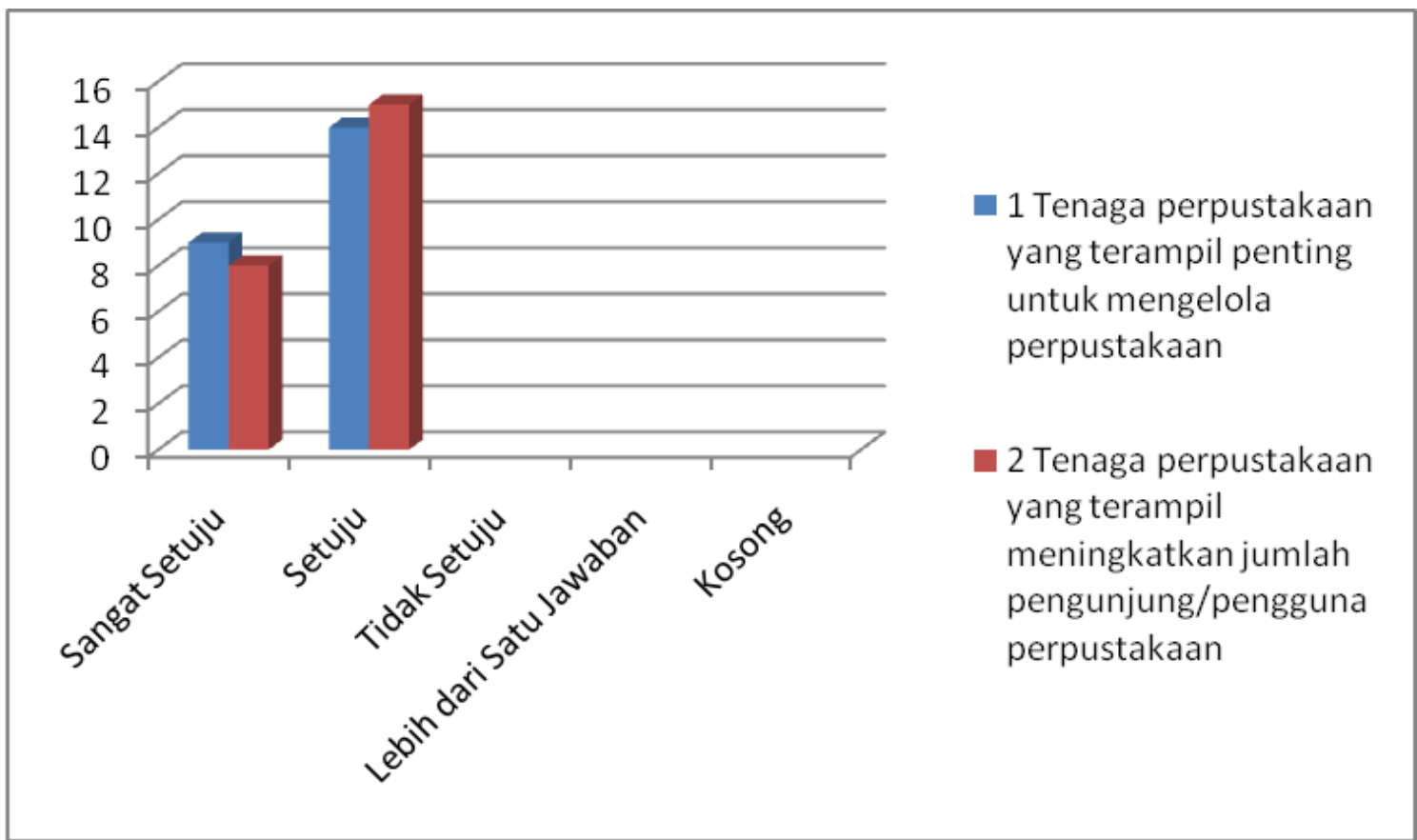

Dari hasil angket diatas, diperoleh pendapat masyarakat bahwa perpustakaan yang terampil penging untuk mengelola perpustakaan karena mampu untuk meningkatkan jumlah pengunjung atau pengguna masyarakat Desa. Dari pendapat tersebut, alangkah baiknya apabila Pemerintah Desa memiliki pustakawan yang handal dan memiliki SDM yang baik dalam mengelola dan mengembangkan perpustakaan desa agar dapat memberikan kontribusi kepada masyarakat desa dalam mengembangkan diri. Rekap kegiatan diatas dapat diringkas dalam tabel berikut ini

\section{Tindak Lanjut Dan Monitoring Serta Evaluasi}

Tahap ini dilakukan setelah proses PPM selesai dilakukan. Agar Program yang diberikan kepada masyarakat dapat memberikan manfaat dan dapat digunakan untuk mengembangkan potensi masyarakat di Desa Kepunten Kecamatan Tulangan, Kabupaten Sidoarjo,maka tim prodi memberikan koneksi kepada tim prodi PPM Pendidikan Bahasa Inggris kepada pemerintah desa setempat agar tetap dapat saling berinterkasi dan memberikan masukan serta informasi yang dapat digunakan dalam mengembangkan dan mengelola perpustakaan desa. Angket yang diberikan kepada masyarakat dapat digunakan untuk monitoring serta evalusi terhadap program PPM tersebut agar dapat memberikan dampak yang signifikan dalam mengembangkan poetensi dari dalam diri masyarakat melalui perpustakaan Desa. 


\section{KESIMPULAN}

Demikian laporan kegiatan Program Pengabdian Masyarakat Prodi Pendidikan Bahasa Inggris yang dapat kami laporkan sebagai pelaksanaan agenda Kegiatan Tri Darma Perguruan Tinggi dan berharap apa yang kami sampaikan sebagai bentuk pengabdian terhadap masyarakat dapat memberikan kontribusi kepada masyarakat di Desa Kepunten, Kecamatan Tulangan Kabupaten Sidoarjo Provinsi Jawa Timur. Atas dukungan dari Lembaga Penelitian dan Pengabdian Kepada Masyarakat Universitas PGRI Adi Buana, Fakultas Keguruan dan Ilmu Pendidikan serta Pemreintah Desa setempat kami mengucapkan terima kasih.

\section{REFERENSI}

Badan Perpustakaan Provinsi Kalimantan Timur. (2014). Harapan dan Tantangan Perpustakaan Desa. Diakses dari http://www.perpustakaan.kaltimprov.g o.id

Perpustakaan Nasional RI. (2006). Penyelenggaraan Perpustakaan Desa. Jakarta: Perpustakaan Nasional RI

Perpustakaan Nasional RI. (2002). Pola dan Strategi Pengembangan Perpustakaan dan Pembinaan Minat Baca. Jakarta: Perpustakaan Nasional RI.

Sutarno, N.S. (2008). Membina Perpustakaan Desa: Dilengkapi Undang-undang. 